${ }^{1}$ Department of Pediatrics, University of California San Diego, San Diego, California, USA

${ }^{2}$ Department of Neurosciences and Pediatrics, University of California San Diego, San Diego, California, USA

Correspondence to

Dr John Ross Crawford, jrcrawford@ucsd.edu

Accepted 31 March 2014
CrossMark

\section{To cite: Wong V,} Crawford JR. BMJ Case Rep Published online: [please include Day Month Year doi:10.1136/bcr-2014204528

\title{
Extensive subdural spinal enhancement mimicking leptomeningeal disease in a young child with posterior fossa tumour following lumbar puncture and surgery
}

Victor Wong, ${ }^{1}$ John Ross Crawford ${ }^{2}$

\section{DESCRIPTION}

A 4-year-old girl presented to the emergency room with a 2-month history of progressive vomiting and ataxia. Initial workup included a lumbar puncture (LP) that led to rapid neurological decline. Emergent CT of the head revealed a large fourth ventricular tumour and hydrocephalus. Following emergent suboccipital craniotomy and resection, pathology confirmed the diagnosis of atypical teratoid rhabdoid tumour. MRI of the spine obtained on postoperative day 1 was concerning for widespread leptomeningeal disease (figure 1). However, cerebrospinal fluid (CSF) analysis showed no malignant cells with normal cell count, glucose and protein. Upon further review, the subdural spinal enhancement was more likely the result of intracranial hypotension from the initial LP and postsurgical effect as has been reported. ${ }^{1}$ Follow-up MRI of the spine 3 months later demonstrated resolution of the enhancement seen on the initial MRI of the spine, ruling out leptomeningeal spread (figure 2).

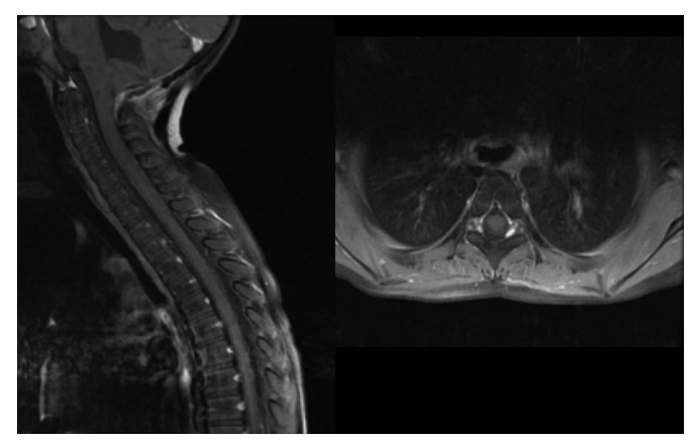

Figure 2 Postgadolinium sagittal and axial MRI of the spine performed 3 months after the initial surgery revealing no evidence of abnormal enhancement.

The diagnosis of leptomeningeal spread is based on neuroradiological findings in conjunction with CSF analysis. Leptomeningeal disease on MRI shows an enhancement pattern that can be varied from a fine linear signal to thicker coating to the 
common nodular/studded appearance. ${ }^{2}$ The finding of subdural enhancement is non-specific and can be attributed to infection, inflammation or intracranial hypotension. Although the frequency of this phenomenon is unknown, the extent of

\section{Learning points}

- Spinal subdural enhancement may mimic leptomeningeal disease in cases following neurosurgery or lumbar puncture and should be correlated with cerebrospinal fluid analysis.

- MRI of the entire spine should be performed prior to surgery whenever possible to more accurately evaluate for leptomeningeal dissemination. subdural enhancement can vary with all reported cases resolving over time. ${ }^{1}$ This case demonstrates the difficulty in diagnosing leptomeningeal spread and the importance of making an accurate diagnosis to potentially avoid unnecessary treatment with high-dose craniospinal radiation therapy.

Competing interests None.

Patient consent Obtained.

Provenance and peer review Not commissioned; externally peer reviewed.

\section{REFERENCES}

1 Shaw DW, Weinberger E, Brewer DK, et al. Spinal subdural enhancement after suboccipital craniectomy. AJNR Am J Neuroradiol 1996;17:1373-7.

2 Porto L, Kieslich M, Bartels M, et al. Leptomeningeal metastasis in pediatrics: magnetic resonance image manifestations and correlation with cerebral spinal fluid cytology. Pediatr Int 2010;52:541-6.

Copyright 2014 BMJ Publishing Group. All rights reserved. For permission to reuse any of this content visit http://group.bmj.com/group/rights-licensing/permissions.

BMJ Case Report Fellows may re-use this article for personal use and teaching without any further permission.

Become a Fellow of BMJ Case Reports today and you can:

- Submit as many cases as you like

- Enjoy fast sympathetic peer review and rapid publication of accepted articles

- Access all the published articles

- Re-use any of the published material for personal use and teaching without further permission

For information on Institutional Fellowships contact consortiasales@bmjgroup.com

Visit casereports.bmj.com for more articles like this and to become a Fellow 